This is an electronic reprint of the original article. This reprint may differ from the original in pagination and typographic detail.

Author(s): Korhonen, Pekka

Title: Changing definitions of Asia

Year: $\quad 2012$

Version:

Please cite the original version:

Korhonen, P. (2012). Changing definitions of Asia. Asia Europe Journal, 10(2-3), 99-

112. https://doi.org/10.1007/s10308-012-0323-5

All material supplied via JYX is protected by copyright and other intellectual property rights, and duplication or sale of all or part of any of the repository collections is not permitted, except that material may be duplicated by you for your research use or educational purposes in electronic or print form. You must obtain permission for any other use. Electronic or print copies may not be offered, whether for sale or otherwise to anyone who is not an authorised user. 


\title{
Changing Definitions of Asia
}

\author{
Pekka Korhonen \\ Professor of World Politics \\ Department of Social Sciences and Philosophy \\ P.O.Box 35 \\ FIN-40014 University of Jyväskylä \\ FINLAND \\ pekka.a.korhonen@jyu.fi \\ +358505631864 \\ absolutely no fax
}


Abstract

The meaning of Asia has changed drastically during the millennia when the concept has been in use. Its usage was established in Greek literature 2500 years ago as a geographic reference to lands inhabited by the Greeks at the eastern side of the Aegean Sea. Over the ensuing centuries Asia's western boundary was extended to the rivers Don in the north and Nile in the south. At that time it hardly contained any definite political or civilizational meanings. These were added to the concept strongly in 1730 in a kind of Swedish-Russian cooperation when the Urals were redefined to form the boundary between Europe and Asia, the former starting to represent progress, and the latter its opposite. This situation has been gradually changing after World War II, when first definitions made in the United States, and later in East Asian countries have devalued the position of Europe and elevated that of Asia. Today Asia is not a geographical concept. It is a political commonplace, used as a strong and positively loaded linguistic asset in political rhetoric in the Asian Pacific area for various kinds of regional integrative purposes.

Keywords

Asia, Europe, boundary, commonplace, civilization, integration

\section{Asia as a commonplace}

The purpose of this article is to analyze changes in the understanding of Asia with respect to Europe. Everybody knows nowadays that something is happening in Asia; it is "rising", and gaining in importance not only in world economics, but also in world politics and culture. On the other hand, as seen from the pre- Euro Crisis highly moral European standpoint, Asia is also full of beggars and child labour, breaches of copyright laws, ethnic and religious terrorism, it lacks democracy and struggles with human rights issues in general (European Union 2011). Diseases, such as the Bird Flu and Swine Flu a few years ago, derive from Asia, and Asia as non-Christianity is even attempting to invade the European Union in the form of illegal immigrants and Turkey's application for membership. What is this Asia referred to in contemporary narratives of progress and securitization, and how does it relate to Europe? Asia appears in these discussions as a commonplace, a rhetorical element that does not need definitions; it is simply used. Commonplaces are handy devices in politics (Korhonen 2012). Commonplace simply means a concept, phrase, saying, maxim, or slogan that is well known and frequently used. The reason why it is a 'place' in English, Gemeinplatz in German, or lieu commun in French, derives from the history of classical rhetoric. Its origin is the concept of кoเvós tótros used by Aristotle in his Rhetoric. In his time a common method for memorizing 
meaningfully a great number of things was to associate them with places, such as houses along a street; things under one type of theme within one house, other themes with other houses. For an enterprising rhetor the important things to memorize were of course skilful sayings and maxims. When a public debate touched upon such a theme, including education, bravery in war, gods, and so forth., the rhetor had in a certain 'place' in his memory street a ready collection of handy phrases immediately usable in the debate. The category of well-known phrases as such also became referred to as a commonplace, as everyone had memorized them. Aristotle gives the following observations of the usefulness of such phrases in practical situations:

To declare a thing to be universally true when it is not is most appropriate when working up feelings of horror and indignation in our hearers [...] Even hackneyed and commonplace maxims are to be used, if they suit one's purpose: just because they are commonplace, every one seems to agree with them, and therefore they are taken for truth. [...] One great advantage of Maxims to a speaker is due to the want of intelligence in his hearers, who love to hear him succeed in expressing as a universal truth the opinions which they hold themselves about particular cases. [...] It is this simplicity that makes the uneducated more effective than the educated when addressing popular audiences makes them, as the poets tell us, 'charm the crowd's ears more finely'. Educated men lay down broad general principles; uneducated men argue from common knowledge and draw obvious conclusions. (Aristotle 2007 II, 22-3)

Commonplaces are effective simply because they are commonplaces. Everyone gets some kind of meaning easily when a commonplace is uttered. The characteristics of commonplaces is that they have a large field of possible meanings, and they are in heavy everyday usage all over the world, so that billions of people have some kind of image of what it means - including lots of curious, dim, and totally mistaken images. This characteristic of multiple unclear meanings is the essence of commonplaces. These meanings are formed from a tangle of historical usages of the word by different persons, in differing contexts, and in various languages. Commonplaces are not aimed at a deep-level common understanding of clear meanings. Exactly for this reason, they are superbly usable in politics, because unclear meanings are of the essence of much politics. A commonplace is most of all a communicative word, meaningful in contemporary everyday discourses. Commonplaces are devices for creating agreements in the form of verbally shared realities. A speaker may say something about Asia, and part of the audience can understand the word in one way, and another part in another way, yet they all can have a shared experience of having discussed Asia.

An example is the special issue of the Journal of Asian Studies, published in the United States, on the meaning of the concept of Asia. The main article was written by Prasenjit Duara, a renowned Indian historian of Asia, who has done most of his career in the United States, and is currently based at the National University of 
Singapore. The other five authors acted as commentators to Duara. All six authors were able to discuss various historical visions of Asia and its integration into a region, as well as flows and circulations of goods, investment, people, religions and ideas in general, without ever getting to the issue of "where" Asia would be situated, and who would be the participants of this integrative process. There appeared to be even conscious avoidance of the issue, because it was too complicated, and in practice quite unnecessary for the flow of discussion. No geopolitical definitions were needed, because Asia has turned into a commonplace, and anyone can enter the discussion with any kind of arguments, especially if they relate to "flows" and "circulations". The closest approximation of a definition of Asia was this:

... region formation in Asia is a multipath, uneven and pluralistic development that is significantly different from European regionalism. Moreover, the region has no external limits or territorial boundaries and does not seek to homogenize itself within. Individual nations, economic, regulatory, cultural entities, and non-governmental organizations have multiple links beyond the core, and when a country beyond the core arrives at the threshold of a sufficiently dense set of interactions and dependencies with it, it may be brought within the region's framework of governance. (Duara 2010, 981)

The argument that Asia is a continuously widening and deepening integrative process without outer boundaries is in itself plausible, but what is interesting is that this process is being set in contrast to Europe. In other words, a dichotomy is created with Asia and Europe as opposing poles, with the implication that Europe is the internally homogenizing boundary builder against external areas. Moreover, Prasenjit Duara, as well as most of the other discussants, embody in their persons these continuous flows, as they move freely from an Asian country to another, and between the United States and Asia. It may be telling that the only discussant with a European origin, Rudolf Mrazek, is somewhat out of touch with the discursive style of the other participants, tending to get distracted into issues of time, morality, globalization and existential philosophy (Mrazek 2010). We shall come back to this European out-of-touch aspect later, but let us take first a look at the history of European eastern boundaries, especially towards Asia.

2. The Aegean, the Don and the Urals

The Aegean Sea is often mentioned as the historical dividing line between Europe and Asia. This is indeed so, but less clear is what this actually means, if it means anything. It is often meant to mean a civilizational boundary, i.e. a boundary separating European and Asian 'civilizations'. Duara probably refers to this when he 
writes that "Asia was merely the name of the area east of the Greek ecumene in ancient times" (2010, 963). There are two mistakes in this argument. First, the

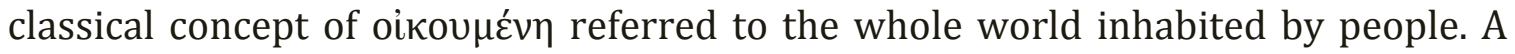
"Greek ecumene" is a misnomer, moreover so because the Greeks did not see any essential civilizational division between themselves and other classical civilizations. We should rather speak of a Mediterranean civilization, of which the Greeks were a part, as Martin Bernal has argued (1987). Second, Asia was not somewhere east of the Greek lands, but quite the opposite; most of Greek civilization was made in Asia, which simply means east of the Aegean here. Homer, Thales, Anaximander, Hecataeus, Herodotus, Arrian and Strabo were born and lived in Asia proper. The Hippocratic school was situated in Kos on the coast of Anatolia, while Ptolemy was born and did his life work in Egypt. Egypt is also where Strabo did his geographical studies. Furthermore, much of Plato's thinking, especially in the Republic, was based on his time of study under Egyptian sophists in Heliupolis on the Nile. Only Aristotle and Thukydides built most of their careers west of the Aegean. In his history of Greeks and Persians Herodotus considered the two people similar: same customs, same culture, same gods, with only different names. Of course the languages were also related (Herodotus 1990). It is self-evident that Greek literature and intellectual life flourished where it was constantly fed by scholars and works of other nations in Asia proper and Egypt; Greek culture did not invent itself out of nothingness. Classical Greece as a civilization should thus be placed in the eastern Mediterranean between the Black Sea and the Nile, with most works on geography and cosmology being written in Asia proper. Greek culture simply was part of Egyptian and Mesopotamian civilizations. It is also evident that the civilized Greeks definitely were not 'Europeans', because in the ancient world, Europe meant the cold northern areas inhabited by roaming bands of barbarous nomads, and there was no interest among the Greeks to identify with them. The Aegean turns into a political boundary only after the end of the Greco-Turkish War in 1922. Before that Greek foreign

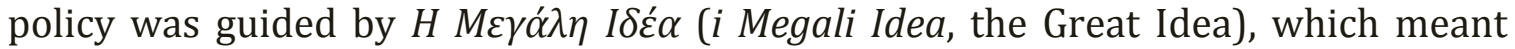
conquering ancient Greek lands in Asia Minor and the creation of a Euro-Asian empire (Rasku 2010).

From the Aegean the geographic boundary went south to the Nile, thus dividing what we now understand as Africa into two halves. Again this is an indication that the ancient continental division was not civilizational, but simply geographical. To the north it went to the Don. When the Greeks sailed northeastwards to the Black Sea, the Don was a mighty waterway that they encountered at its farthest corner, and thus a suitable continuation of the continental division. This situation lasted well into the seventeenth century, when the gradual consolidation of the modern nation-state, mixed with religious ideology, began to influence also this continental division. Here civilizational meanings strongly start to permeate the geographic ones, eventually overcoming them. Of course, the prevalent state form in Europe at the time still was the multinational empire, not the small cohesive state we know nowadays, but anyway imperial boundaries began to be seen also as civilizational boundaries. The Swedish, Polish, and Austrian empires were clearly included within Christian Europe, but the Ottoman, Mongolian and Russian empires to the east were not. The Ottoman and western Mongolian empires 
were predominantly Muslim, while Orthodox Russia was a little-known political entity far to the northeast, difficult to conceptually separate from Muslims (Parker 1960, 281-4). The continental boundary could not simply be drawn along imperial borders, because they changed easily, which was geographically improper in case of such grand entities as continents. The practical expedient was to draw the boundary along the River Dnepr and then to the White Sea in a number of European maps published during the seventeenth century, although by no means in all of them. Ancient Greek notions came under scrutiny here and there, but this involved no general and public scholarly discussion of the matter (Korhonen 2006).

The next step was discarding Greek geography. This brings us to the invention of the best-known boundary issue, namely to the idea that the boundary between Asia and Europe lies in the Ural Mountains. The idea has been propagated throughout the world in education of geography in schools. School atlases in practically everywhere in the world place the boundary there. Indeed, if you take a taxi in the Siberian city of Yekaterinburg in the eastern side of the Urals, and are comfortably driven to the top of the magnificent mountain range, you will indeed find there a concrete monument showing the exact location of the boundary, with the names Азия and Европа written on it. This is an impressive sight. Simultaneously, you are also impressed by the total lack of any kind of mountains in sight. You are in a gently undulating country of low hills and soft valleys, covered by spruce and pine, where nothing indicates the geographic presence of a boundary separating Asia and Europe from each other. You start to realize that you are witnessing a grand monument for political rhetoric.

The boundary was transferred from the Dnjepr to the Urals in Philip Johan Stralenberg's book Das Nord und Ostliche Theil von Europa und Asia, published in Stockholm in 1730. Stralenberg was a Swedish army officer, who spent 11 years in captivity in Siberia during the Great Northern War, and after his release he brought to Europe new Russian geopolitical thinking. This was the early period of European Enlightenment, with its emerging narrative of progress. The narrative spread from the west to the east and its content was that Europeans had become a people, whose astounding achievements in the development of sciences, technology, and overseas conquest dwarfed the achievements of all previous generations (Parker 1960, 280). Progress became the new rhetorical element shaping the conceptualization of continents, with Europe at the top, everything else inferior to it. Simultaneously, Europe became essentialized as an absolute value, from which everything else was judged.

The characterization of Europe as progress was most pronounced in the maritime Atlantic states, especially the Netherlands, Britain and France. They formed Europe par excellence, and other nations participated in Europeanness to the extent that they also could be depicted as progressive. Pure geography was rhetorically weak in this ideational climate, if it did not contain this narrative of progress. This can be seen also in Stralenberg's argumentation. He discussed to some extent possible rivers as markers for the European and Asian division, found them all unusable, and then simply claimed that the Ural Mountains should be adopted as the new continental boundary (1975/1730, 106). His geographical arguments for this were rather weak, as he claimed, for example, that European 
riverbanks are covered by small coloured stones, Asian riverbanks by grey rock; or that rivers on the western slopes of the Urals run to the west, while on the eastern slopes they run to the east. These are quite insignificant or tautological arguments, if we consider that the issue at hand was redrawing the boundary between Europe and Asia. Something more weighty should have been presented to challenge the Greek tradition of placing the boundary at the River Don. It was more than a millennium old, and still respected even by Stralenberg himself. It could not be displaced directly.

Stralenberg's argumentative strategy was to argue that Russia itself was European, rather than Asian. He pointed out that Russia had thus far been considered as a pagan, barbarian, and non-progressive nation similar to the Mongols, because Europeans had not had enough correct information of the empire. Stralenberg set out to rectify the situation by enumerating the achievements of Peter I. The ambitious Czar had established a great empire through wars with the Chinese, Turks, Swedes, Persians and Kalmyks. He had put Russian fleets to the Baltic, White, Pacific and Caspian Seas, and built up a capable army following the example of the most civilized (allercivilisirtesten) nations, which of course referred to western European nations. Likewise he had erected in Russia strong fortresses, all built with the best European engineering skills. He had spread throughout his empire the knowledge of sciences and foreign languages, maintained Russia as a devout Christian country, and reorganized the Russian administrative system. He had strengthened Russian economic resources by establishing big populous towns, and by building roads and canals to facilitate trade. To finance this, he had increased mining and manufactures. Russian economic output had become 5 or 6 times bigger than before, easily enabling the payment of the costs of lengthy wars and construction projects. Stralenberg also argued that Czar Peter used to sleep only four hours a night, spending the remaining twenty hours working for his country, and personally studying the legal and administrative systems of European states. On top of all, the personality of Peter was pleasant, as he was good-natured, friendly, hard-working, and had not become arrogant, in spite of his position and achievements. The picture Stralenberg paints of Peter I was similar to that of a frugal and successful protestant Dutch entrepreneur, and it fit perfectly with the Enlightenment narrative gathering strength in contemporary Western Europe. Should not such a progressive country under such an admirable leader be considered European, rather than Asian?

It is only within this Enlightenment argument that the idea of the Ural Mountains as a continental marker makes sense. If not much of a geographic boundary, the Urals nevertheless were a logical civilizational boundary from a Russian point of view. Russia and Siberia were clearly different entities in Russian understanding (Bassin 1991a, 7). Russia had a traditional agricultural economy under the Orthodox Church and imperial administration, while Siberia was a wild area populated by pagan nomads and Russian fur traders. It could not be effectively governed by anyone. What in Stralenberg's book appeared as a geographic European and Asian boundary, and later was accepted in Europe as such, was originally an intra-Russian division of civilization and way of life. At that time Russians had become very proud of their achievements, and started to consider 
themselves on the same terms as western empires. After the victory over Sweden in 1721 Peter I abandoned the old idea of Muscovy as a czardom, and instead his rank was proclaimed to be imperator. Simultaneously Russia was ceremonially proclaimed to be an imperiia, similar in rank with Spain, France and Britain. Later during the nineteenth century Siberia was consistently 'Asianized' in Russian discussions, employing colonial images adopted from British and French colonial literature. The Russian empire was conceptually divided into a European metropolis in Russia and its Asian colony in Siberia.

Notwithstanding, this represented the mature phase of an established discourse; during the Petrine period the necessity arose to establish the rhetorical redescription of Russia in the first place. It has been pointed out that the Petrine period is one of the first occasions in Russian history when Europe was taken into purposeful political use as a speech act; earlier the concepts of Europe and Asia had simply been irrelevant, of no concern in Russia, which simply had been a pure Orthodox realm (Neumann 1996, 2-12; Lewis and Wigen, 1997, 27-8). With the acceptance of the cultural and epistemological superiority of Atlantic Europe, the principal audience of Russian rhetoric also shifted to the West. Russia first had to be accepted there as a European country, and only after that it could pose as a European empire colonizing vast tracts of backward Asia. This rhetorical redescription turned out to be very successful. With Stralenberg's effective Enlightenment-style argumentation Russia left Asia and entered Europe. Stralenberg's book attracted considerable attention around Europe, where knowledge of Russia as a new military power caused demand for accurate information. Reprints were taken of the original German edition, and it was also translated into English (1738), French (1757), and Spanish (1786). With this publicity, the Urals inconspicuously became the new continental boundary, and appear nowadays as such in school geography all over the world.

While the narratives of progress and conquest were thus attached to the name of Europe, Asia began to resemble everything opposite, a place to be conquered and colonized. Geography as such became irrelevant in Eurasian geopolitical discussions. Civilizational and political ideas overrode it, although this could be clothed under the use of geographic concepts, in the same way that Stralenberg did. From this time onwards argumentative concordance, with the exception of the Oriental Renaissance of the nineteenth century (Schwab 1984), began to influence nearly everything written about Europe and Asia. Europe as a civilizational continent systematically represented a higher type of entity at the ruling top of the world, while Asia equally systematically was assigned to a lower and weaker position (Korhonen 2010). This specific historical phase has nevertheless been studied thoroughly by others (see, e.g., Bernal 1987, Said 1995, Kiernan 1995, Lewis and Wigen 1997) and is so well known that I shall not touch more of it here.

3. The post-World War II rise of rhetorical continents 
Interesting changes began to take place yet again after the Second World War, when the United States and the Soviet Union replaced European powers as dominant geopolitical definers of regions in the world. Concepts, such as the West, changed drastically. The United States as the world hegemonic power became the central actor of the West, and its military allies filled the peripheries of the concept, ranging from Japan and Australia to Turkey and Iceland. Europe was cut into two halves, western and eastern, and the division went through formerly unified nation-states, such as Germany (Jackson 2006). The change of geopolitical hegemony of course had to be argued publicly, and this can be clearly discerned in American postwar discussions, where old European naming practices were attacked. For instance the American geographer George B. Cressey argued in 1951 strongly against such established names as the Near East and Far East, because they were meaningful only from a Eurocentric point of view. They were not logical to Americans, nor to Asians (Cressey 1951, 12). The Americans observed the Eurasian landmass both from the west and from the east over the Pacific Ocean, so that near and far became relative, depending on the direction of the gaze. The British had actually proposed during World War II changing the name of Near East to Middle East, but at that time the American government had not been interested. During the 1950s they became active nominalistically, and in US State Department texts the geographic core of the Middle East began to mean the area from Libya in the west to Pakistan in the east; from Turkey in the north to the Arabian peninsula in the south. Secretary of State John Foster Dulles began to use this definition in 1957. However, because it was a strategic concept, used for planning and implementing US foreign policy in the area, also adjacent states, such as Algeria, or conflict-prone subnational regions like Kashmir, were included in it according to the situation (Oikarinen 1999, 20-21). Post-colonial nationalism, border disputes and ethnic conflicts, islam and oil, as well as Cold War competition between Capitalism and Socialism tended to characterize the region. This usage was then spread around the world in mass media, and the Middle East turned into an ordinary commonplace in heavy everyday usage. Its practical effect was that this piece of the world was rhetorically cut off from Asia and Africa, as these older names ceased to be used in connection with it. As a commonplace, the Middle East became a separate "continent". This was possible, because after centuries of civilizational geopolitics, continents were no more geographic entities, but rather geopolitical and strategic concepts, with cultural, political and economic contents.

It is interesting that in some continental European languages the name of the region did not change. In French it is still usually Proche-Orient, although also Moyen-Orient, as translation of Middle East, is used to some extent. In Spanish it is Oriente Próximo, in German Nahe Osten, in Polish Bliski Wschód, in Finnish Lähi-Itä, in Estonian Lähis-Ida, in Russian Ближний Восток. Nevertheless, the geopolitical meaning of these names is the same as the American Middle East. In some other languages the name has been changed to correspond with the new strategic geography, such as the Swedish Mellanöstern, Islandic Mid-Austurlönd, Dutch

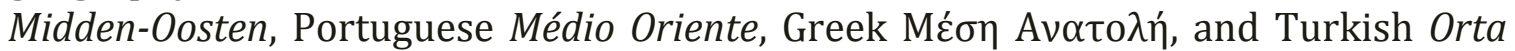
Doğu, Middle East. An older European-centred nominalistic layer still persists in a number of countries, but overall the meaning has changed irrespective of the name 
used, and Europeans nowadays categorize geopolitics of the region in the same way as Americans do. Simultaneously, the name West Asia, which was not too heavily used even before World War II, has further declined in the post World War II period, and is only very seldom seen in any kind of modern text. In this way the region, which first came to be called Asia in classical antiquity, has gradually been forced out of Asia, to form a specific geopolitical region of its own.

Cressey argued also against using the Urals as a continental boundary marker, calling it an arbitrary line, which followed no significant geographic, climatic, cultural, or historical division (Cressey 1951, 12). After three centuries of Russian rule the relative cultural and religious differences that had existed at the time of Peter I between Siberia and Russia had disappeared. Moreover, instead of Russia, the power that now confronted the United States in the northern part of Eurasia was the Union of Soviet Socialist Republics, a nuclear power with a vast territory. That territory was especially huge in maps drawn according to the Mercator projection, still usually employed during the early post-war period. The USSR was a geopolitical unity, a central Eurasian and global actor, not a peripheral far-away country that could be divided into two halves according to centuries old European geographical notions. The Ural mountains as a boundary miraculously survived in school book geography, but geopolitically it had no meaning.

The geopolitical map of the Eastern hemisphere was redrawn after the end of the Cold War. Visual forms appeared for instance in the year book of the Japanese Ministry of Foreign Affairs in 1990, which showed how the ministry categorized the Eurasian geopolitical situation as composed of five basic areas (Gaimushō 1999). However, verbally the ministry had been using a similar classification since 1957 (Gaimushō 1957). This geopolitical innovation meant presenting the old world as composed of five "continents", namely Europe, Asia, Africa, the Middle East, and the former USSR as a loosely unified region. It neatly combined American post World War II world view with the post Cold War situation. The old classical continents, Asia, Africa and Europe appear in reduced geographical forms. Europe, which had been divided into Western and Eastern halves during the Cold War became unified, and it has taken an organizational shape in the form of the European Union. It is interesting to note that the eastern boundary of the contemporary EU runs roughly along the same line where the European eastern boundary had often been placed during the sixteenth and seventeenth centuries, before Stralenberg rhetorically moved it to the Urals. Deep historical factors seem to be working here simultaneously with everyday political constellations. The former USSR as a postsocialist geopolitical region still exists in the form of the Commonwealth of Independent States (CIS). The demise of Communism as the main common enemy of the American-led Western coalition has been replaced by radical Islam, which increasingly has heightened the image of the Middle East as a special and separate geopolitical region. And finally, economic and social development, rapid increase in mutual economic interdependency, and tentative attempts at regional institutionbuilding have led to a perception of Asia as a more clearly defined separate region than ever before. It acts no more as a place where redundant areas that are not wanted within Europe are placed, but as an integrating geopolitical core area in its own right. Asia can be said to consist of a group of countries with Japan and Korea in 
the eastern end and India in the west; China and Mongolia in the north. Indonesia could form the southern end, but the post-World War II crumbling of European colonial empires has resulted in a situation where Australia and New Zealand are increasingly seen as parts of Asia, and all European colonial possession in Asia have disappeared, the last one being Macao in 1999. In this geopolitical scheme, Europe and Asia do not even touch each other any more. They have no mutual boundary.

\section{Asia as organizations}

As seen earlier, Duara attempted to conceptualize the region as it is at present as a collection of material and immaterial flows under the commonplace of Asia, without any attempt to define national participants or borders. This may be sensible for a person who is part of the flows, in the middle of action, constantly observing and sensing the dramatic changes taking place, seemingly without end. From a more distant European perspective an attempt to give more concrete definitions might, however, be in order; even if for no other reason, then at least for the purpose of trying to hammer on European consciousness the fact that the world has changed irreversibly, and old European geopolitical notions no longer are relevant in world politics.

Students of international relations would opt for explaining Asia through a process of international organizations established during the past decades. They are something tangible. They have names, often - though not always with the element 'Asia' in them, so that you can empirically point them out as clear practical definitions of a region. (Korhonen 2011) This is the solution of, amongst others, Amitav Acharya, an Indian born Canadian working currently at the American University in the United States, specialized in Southeast Asian politics. The first Asian international organization was a Japanese creation during World War II, namely the Greater East Asia Coprosperity Sphere (大東亜共栄圈 Dai Tō-A Kyōeiken), composed of the Japanese empire, Manchukuo, China, Thailand, Burma, the Philippines, French Indo-China and Dutch East Indies, with Subhas Chandra Bose as a representative of Free India also participating in various events. This list is not actually very different from the core area of Asia as it is understood nowadays, which attests to the fact that European definitions of Asia, which dealt with it as a residual geographic category, were not relevant elsewhere even at that time. As a matter of fact, Japanese interpretations of Asia systematically have been rather innovative over the centuries. They have steadfastly used their own points of view, not that of the Europeans (Korhonen 2008). This kind of interest in an exclusive Asian organization was not limited to the Japanese. Also important political figures such as Ho Chi Minh in Vietnam, Aung San in Burma, Sukarno in Indonesia, and Jawaharlal Nehru in India expressed the idea after the war, leading to two expressly anticolonial Asian Relations conferences in 1947 and 1947 in India, and a decade later to the Asian African Conference - later renamed the Bandung Conference - in 1955 in Indonesia (Acharya 2010). This was the launching step of the non-Aligned Movement, which during the later decades spread throughout the world, at its 
largest including countries from Latin America, such as Argentina and Cuba, and European neutrals, such as Yugoslavia and Cyprus. It still exists, with over 120 members and observers, mostly developing countries, but its importance is much more limited and it no longer has a specific Asian character.

Another stream of organizations were created at the eastern end of the Eurasian landmass. One of these was on Korean initiative, namely the Asia Pacific Council (ASPAC). It held its first ministerial meeting in 1966 in Seoul, with South Korea, South Vietnam, Taiwan, Japan, Thailand, the Philippines, Malaysia, Australia and New Zealand as founding members. However, although there were definite attempts not to make it a Cold War organization with military undertones, it never was able to free itself from an aura of an anti-Communist organization, and finally it collapsed in 1975 (Braddick 2006, 30-46). Organizations established by Japanese and Australian initiatives tended to last longer. As there was a tendency to leave Japan out of much post-World War II Asian cooperation, and Japan had been placed fairly tightly under United States control, the Japanese geopolitical frame in the 1960s tended to be the Pacific rather than Asia. 1967 saw the establishment of an apparently non-political and non-state business leaders' organization called the Pacific Basin Economic Council, followed in 1968 by the creation of an informal academic conference series of economists called The Pacific Trade and Development (PAFTAD) conferences. Their nucleus was Japan, Australia, New Zealand, the United States and Canada, but their membership quickly spread to various Asian and Latin American countries. Despite their apparent non-political character, in practice they acted as important diplomatic tentacles, in whose conferences a groundwork was laid for the establishment of first a bureaucratic OECD-type of organization, namely the Pacific Economic Cooperation Council (PECC) in 1980. This would result in the formation of an openly economic and political organization with summit-level meetings, the Asia Pacific Economic Cooperation (APEC), in 1991 (Korhonen 1994; 1998). The Association of Southeast Asia (ASA) was formed by the Philippines, Malaysia and Thailand as the Non-Aligned movement was getting out of hand, followed by the Association of Southeast Asian Nations (ASEAN), established in 1967 by Indonesia, Malaysia, the Philippines, Singapore and Thailand. Its membership has since been expanded to include Brunei, Burma/Myanmar, Cambodia, Laos, and Vietnam. ASEAN has acted as the practical nucleus for two other organizations, one of them being the ASEAN Regional Forum (ARF), dedicated to discussions on security. Despite its name the ARF is of a global character counting the United States, Russia and the European Union among its members. It is actually the only important Asian organization where the $\mathrm{EU}$ is a member, excepting the Asia-Europe Meeting (ASEM), established in 1996. The other organization around ASEAN did not have a specific name, but used to be called only the ASEAN+3, including regular meetings by ASEAN states with China, Korea and Japan. In 2005 these meetings were upgraded to the East Asia Summit (EAS), which nowadays is probably the single most important Asian international organization. EAS membership at present constitutes a familiar collection of countries from India to Japan and from China to New Zealand, with some smaller poor countries, such as Nepal, Bhutan, Mongolia and Papua New Guinea missing, implying that this is an organization for big and medium-sized countries. The United States and Russia 
formally entered as members in November 2011. This may perhaps be taken as one of the possible maps of Asia at present.

\section{Conclusion}

A defining characteristic of Asia nowadays is that it has turned into the global political and economic core area where important states want to be present. Asia has always been an important region, but now its eminent position is rather widely recognized. An example is the US Secretary of State Hillary Clinton's policy speech in 10 November 2011 in Hawaii, where she announced that as the United States is detaching itself from commitments elsewhere in the world, especially Iraq and Afghanistan in the Middle East, it is finally able to focus on Asia:

It is becoming increasingly clear that in the 21st century, the world's strategic and economic center of gravity will be the Asia Pacific, from the Indian subcontinent to the western shores of the Americas. And one of the most important tasks of American statecraft over the next decades will be to lock in a substantially increased investment diplomatic, economic, strategic, and otherwise - in this region. (Clinton 2011)

Clinton of course puts emphasis on the word 'Pacific', as it is a more familiar object of identification for her American audience, but elsewhere in her speech she readily admits that 'Asia' is the first word in the pair. Joining the East Asian Summit a week from Clinton's speech also attests to the fact that even the United States has become willing to refer to itself as an 'Asian state'. Europe remains at the opposite side of the globe, but it is presented as a stable area, with no special promises for the future. Europe is remembered as 20th century history, but in the 21st century history will be made elsewhere. Some European commentators, such as Frans-Paul van der Putten, have duly noted the situation. He points out the odd passivity of the EU towards Asian international organizations. For instance Catherine Ashton, the European Union's High Representative of the Union for Foreign Affairs and Security Policy, has failed to attend any major international meeting in Asia during her two years in office (van der Putten 2011). The EU is a member only of the ASEAN Regional Forum, but Ashton has skipped even its annual meetings, concentrating instead on diplomacy in the Middle East and North Africa. As van der Putten also points out, not attending the ARF meetings regularly and with high visibility at the highest possible level makes it less likely for Europeans to be granted access to other Asian organizations, such as the East Asian Summit. This appears as an absent-minded EU policy for marginalizing itself from the centre stage of world politics.

The maps of Asia will continue to be drawn and redrawn for centuries still. The material and ideational flows and circulations in the region will go on, not necessarily always smoothly, but most likely on an expanding scale for at least a couple of decades. The ending of the demographic expansion and ensuing contraction in working age populations, which has already started in some Asian 
countries, will, however, significantly change the patterns of Asian growth (Ochiai 2010; Wongboonsin and Wongboonsin 2010). This is already leading to rises in wages even in China and its neighbouring countries (Cai 2011), and will lead to shortages of labour in the future, as well as to the shift of perhaps 100 to 200 million unskilled industrial employment opportunities elsewhere, primarily to Africa. This may contribute to more stable international organizations in the future. At the moment they tend to be loose, riding both on the flows and circulations described by Duara, and on the fact that Asia has become a rhetorical commonplace, under which various kinds of actors can easily situate themselves. A third reason is that in situations of rapid change, it is not necessary or beneficial for states to construct rigid international structures, because the mutual relationship of states tends to alter in each decade (Korhonen 2011). All this may change after the transformational process slows down. Asian institutional maps have thus far shown a marked tendency of expansion, as various states around the nucleus of ASEAN + Japan, China and South Korea have pushed themselves into these organizations, but there exists also a counter tendency of trying to build smaller and more efficient organizations. This tendency may become more prevalent as the pattern of change slows down. Nevertheless, this would not easily displace Asia from its central place in the world's economy and polity for decades to come, because what it may start to lack in simple raw economic growth, it will gain in technological, political and military importance.

Bibliography

Acharya, Amitav (2010) 'Asia Is Not One', The Journal of Asian Studies (69) 4, 10011013.

Aristotle (2007) [335-322 BCE] Rhetoric, http://etext.library.adelaide.edu.au/a/aristotle/a8rh/index.html (18.12.2010)

Bassin, Mark (1991a) 'Inventing Siberia: Visions of the Russian East in the Early Nineteenth Century', in American Historical Review (96), 763-794.

Bassin, Mark (1991b) 'Russia Between Europe and Asia: The Ideological Construction of Geographical Space', in Slavic Review (50), 1, 1-17.

Bernal, Martin (1987) Black Athena. The Afroasiatic Roots of Classical Civilization, Vol. I, The Fabrication of Ancient Greece 1785-1985, New Brunswick, NJ: Rutgers University Press.

Braddick, C.W. (2006) 'Japan, Australia and ASPAC. The Rise and Fall of an AsiaPacific Cooperative Security Framework, in Brad Williams and Andrew Newman (eds) Japan, Australia and Asia-Pacific Security, London and New York: Routledge, 
$30-46$.

Cai Fang (2011) 'China's rising wages', East Asia Forum 5.9.2011.

http://www.eastasiaforum.org/2011/09/05/chinas-rising-wages/ (19.12.2011)

Clinton, Hillary Rodham (2011) 'Secretary Clinton's Speech at The East West Center. America's Pacific Century', November 10, 2011, http://seoul.usembassy.gov/p gov 11102011.html

(4.12.2011).

Cressey, George B. (1951) Asia's Lands and Peoples. A Geography of One-Third the Earth and Two-Thirds Its People, New York, Toronto and London: McGraw-Hill.

Duara, Prasenjit (2010) 'Asia Redux: Conceptualizing a Region for Our Times', The Journal of Asian Studies (69) 4, 963-984.

European Union (2011) EU Annual Report on Human Rights and Democracy in the World in 2010, Brussels: European External Action Service, http://eeas.europa.eu/human_rights/docs/2011_hr_report_en.pdf (18.12.2011).

Gaimushō (1957) Waga gaikō no kinkyō, Tokyo: Ōkurashō insatsu kyoku.

外務省（昭和32年）我外交の近況、東京都：大蔵省印刷局。

Gaimushō (1990) Gaikō seisho. Waga gaikō no kinkyō, Tokyo: Ōkurashō insatsu kyoku.

外務省（平成 2 年）外交青書。我外交の近況、東京都：大蔵省印刷局。

Herodotus (1990) [c. 440 BC] Herodotus, Loeb Classical Library, Cambridge, Mass. and London: Harvard University Press.

Jackson, Patrick Thaddeus (2006) Civilizing the Enemy. German Reconstruction and the Invention of the West, Ann Arbor: The University of Michigan Press.

Kiernan, Victor (1995) The Lords of Human Kind. European Attitudes to Other Cultures in the Imperial Age, London: Serif.

Korhonen, Pekka (1994) Japan and the Pacific Free Trade Area. Routledge: London \& New York.

--- (1998) Japan and Asia Pacific Integration: Pacific Romances 1968-1996, London and New York: Routledge.

--- (2006) 'Concept of Asia', in Zeki Kütük (ed.) At the Crossroads of Asia, Africa and Europe, Turku: University of Turku, Department of Contemporary History Researches 29,103-123.

--- (2008) 'Asia and Chinese Civilization. Japanese Uses for the Concept of Asia 16951885'. In International Conference on Conceptual History, Global-Historical Diffusion 
of Western Concepts and the Transformation of Northeast Asian Regional Order, 18-19 September 2008, Seoul: Seoul National University, pp. 127-157.

--- (2010) 'Naming Europe with the East', in Katalin Miklóssy \& Pekka Korhonen (eds) The East and the Idea of Europe, Newcastle upon Tyne: Cambridge Scholars Publishing, 1-21.

--- (2011) 'On the Metageography of Euro-Asia', in Jyrki Käkönen, Sanjay Chaturvedi \& A. Sengupta (eds.), 'Euro-Asia' at the Crossroads. Geopolitics, Identities and Dialogues, Delhi: Shipra, 19-43.

--- (2012) 'What is Asia? International Studies as Political Linguistics', in Pami Aalto, Vilho Harle \& Sami Moisio (eds.), Global and regional problems: Towards an interdisciplinary study, Basingstoke: Palgrave, 131-149.

Mrázek, Rudolf (2010) 'floating. No gears shifting', The Journal of Asian Studies (69) 4, 1021-1025.

Neumann, Iver B. 1996. Russia and the Idea of Europe. A Study in Identity and International Relations. London and New York: Routledge.

Ochiai Emiko (2010) 'Reconstruction of Intimate and Public Spheres in Asian Modernity: Familialism and Beyond', Journal of Intimate and Public Spheres (1) 1, 222.

Parker, W.H. (1960) 'Europe: How Far?', Geographic Journal (126) 278-97.

van der Putten, Frans-Paul (2011) 'Europe in the Pacific century', East Asia Forum 22.11.2011,

http://www.eastasiaforum.org/2011/11/22/europe-in-the-pacific-century/ 4.12.2011.

Rasku, Minna (2010) 'Placing Greece on the Boundary of Europe', in Katalin Miklóssy and Pekka Korhonen (eds) The East and the Idea of Europe, Newcastle upon Tyne: Cambridge Scholars Publishing, 93-117.

Said, Edward (1995) Orientalism. Western Conceptions of the Orient, London: Penguin.

Schwab, Raymond (1984) [1950] The Oriental Renaissance. Europe's Rediscovery of India and the East, 1680-1880, New York: Columbia University Press.

Stralenberg, Philip Johan (1975/1730) Das Nord und Ostliche Theil von Europa und Asia, in so weit solches das ganze Russische Reich mit Sibirien und der grossen Tatarey in sich begreiffet, in einer Historisch-Geographischen Beschreibung der alten und neuern Zeiten, und vielen andern unbekannten Nachrichten vorgestellet, Nebst einer noch niemahls ans Licht gegebenen TABULA POLYGLOTTA von zwei und dreyssigerley Arten Tatarischer Völcker Sprachen und einem Kalmuckischen Vocabulario, Sonderlich aber einer grossen richtigen Land-Charte von den benannten Ländern und 
andern verschiedenen Kupfferstichen, so die Asiatisch-Scythische Antiqvität betreffen; bey Gelegenheit der Schwedischen Kriegs-Gefangerschafft in Rußland, aus eigener sorgfältigen Erkundigung, auf denen verstatteten weiten Reisen zusammen gebracht und ausgefertiget von Philipp Johann von Strahlenberg, Stockholm, in Verlegung des Autoris, 1730;

republished in toto as $\mathrm{Ph}$. J. von Strahlenberg, Das Nord und Ostliche Theil von Europa und Asia, Studia Uralo-Altaica 8, Szeged: Attila József University.

Wongboonsin Patcharawalai and Wongboonsin Kua (2010) 'Demographic Dividend and the Future of Asia', Journal of Intimate and Public Spheres (1) 1, 40-54. 